\title{
Biological efficacy of phyto-synthetic silver nanoparticles using ethanol extract of Euphorbia wallichii Hook Rhizome as bio-reductant and surfactant
}

\author{
Rehman Ullah", Siraj ud Din ${ }^{1}$, Zahir Muhammad ${ }^{1}$, Sumaira Shah², Saiqa Afriq \\ $\operatorname{Jan}^{1}$ \\ ${ }^{1}$ Department of Botany, University of Peshawar, Peshawar, ${ }^{2}$ Department of Botany, Bacha Khan University Charsadda, \\ Pakistan \\ *For correspondence: Email: rehmanbotany@gmail.com
}

\begin{abstract}
Purpose: To synthesize silver nanoparticles using rhizome extract (RE) of E. wallichii as a bioreductant and surfactant.

Method: RE was used as a bio-reductant for the reduction of $\mathrm{Ag}^{+1}$ (aq.) and as a stabilizing agent for silver nanoparticles (AgNPs). The AgNPs were then characterized by UV-visible spectrophotometer, scanning electron microscopy (SEM), dynamic light scattering spectroscopy (DLS), $x$-ray diffraction $(X R D)$, energy dispersive $x$-ray spectroscopy (EDS) and infrared (IR) spectroscopy. The antinociceptive potential of AgNPs was evaluated using Eddy's hot plate. Spasmolytic bioassay was measured in mice via GI charcoal movement test. Anti-leishmanial potency was examined against promastigotes of Leishmania tropica, while antioxidant bioassay was determined using DPPH reduction method.

Results: UV-Vis results showed characteristic surface plasmon resonance band from $440-460 \mathrm{~nm}$, thus confirming the reducing ability of RE. SEM analysis showed spherical AgNPs with a typical face center cubic (fcc) structure as evidence by their x-ray diffraction (XRD) pattern. The role of $R E$ as a stabilizing agent towards AgNPs was supported by IR and electronic absorption spectral data. Phytochemical investigation of RE confirmed the presence of alkaloids, flavonoids, phenols and glycosides etc. Mice treated with RE-AgNPs exhibited dose-dependent analgesic and spasmolytic effects. RE functionalized AgNPs exhibited promising antileishmanial and antioxidant effects $(p<0.05)$. Conclusions: RE-AgNPs exhibit substantial spasmolytic and antinociceptive activity, indicating central and peripheral analgesic effects. Thus, the formulation's antileishmanial and antioxidative effects, indicate that it might be useful for preventing infectious and oxidative stress disorders.
\end{abstract}

Keywords: Euphorbia wallichii, Silver nanoparticles, Antioxidant, Analgesic, Antispasmodic, Antileishmanial

This is an Open Access article that uses a funding model which does not charge readers or their institutions for access and distributed under the terms of the Creative Commons Attribution License (http://creativecommons.org/licenses/by/4.0) and the Budapest Open Access Initiative (http://www.budapestopenaccessinitiative.org/read), which permit unrestricted use, distribution, and reproduction in any medium, provided the original work is properly credited.

Tropical Journal of Pharmaceutical Research is indexed by Science Citation Index (SciSearch), Scopus, International Pharmaceutical Abstract, Chemical Abstracts, Embase, Index Copernicus, EBSCO, African Index Medicus, JournalSeek, Journal Citation Reports/Science Edition, Directory of Open Access Journals (DOAJ), African Journal Online, Bioline International, Open-J-Gate and Pharmacy Abstracts 


\section{INTRODUCTION}

Nanobiotechnology is an interdisciplinary science with the application to the biological systems to manufacture new biochemical system. The transformed nanobiosystems exhibit completely new properties like morphology, density, diffusion rate, catalytic potential and size distribution [1]. Fabrication of nanoparticles via green route enhances physiological potential, much economical and ecofriendly compared to chemical and physical methods which requires high energy, use toxic and expensive chemicals [2].

The modulation of metals into their nanoscale structures by phytometabolites is of vital importance for the development of nanomedicine. Nanoparticles derived from metallic silver, made notable comeback as a potent antimicrobial, antimalarial and as antiangiogenic agent. Thus, AgNPs have diverse applications in modern health system like silver coated medicinal devices, dressings, nanogels and nano-lotions [3]. Plant extracts have the capability to reduce metals ions and to synthesize biogenic nanoparticles, improve their monodispersion and modulate their shapes and sizes. Different transition metals like $\mathrm{Au}, \mathrm{Mn}, \mathrm{Zn}$, $\mathrm{Ti}, \mathrm{Cu}$ and $\mathrm{Ag}$ have been used for the synthesis of nanoparticles but silver was proven to be most effective against bacteria, viruses and other pathogenic microbes [4]. Green and biogenic synthesis of nanoparticles is highly advantageous over both physical and chemical methods for its low cost and eco-friendly method as it avoids the use of high temperature, energy, pressure and toxic hazardous chemicals. Phytometabolites provide a better platform for biogenic nanoparticles as they are providing natural capping agents free from toxic chemicals [5].

Euphorbia wallichii is a himalayan herb, used in tibet as folkloric remedy for curing furuncle, exanthema, cutaneous anthrax and other skin disorders. Stem latex is using for healing external wounds while whole plant is highly laxative and causes severe diarrhea $[6,7]$.

\section{EXPERIMENTAL}

The plant specimen was collected from Abbottabad Pakistan and a voucher specimen (no. Bot.20078 PUP) was submitted to the herbarium of Department of Botany, University of Peshawar, Pakistan. The shade dried and powdered rhizome was subjected to successive extraction by $70 \%$ ethanol and filtrate was evaporated with rotary evaporator at $50 \pm 3{ }^{\circ} \mathrm{C}$.
Rhizome extract of E. wallichii (RE) was screened for different phytomatabolites like reducing sugar, alkaloids, saponins, glycosides, proteins, phenols, flavonoids, phytosterols and tannins as per standard procedures [8].

\section{Biogenic synthesis of AgNPs}

Aqueous solution of RE $(200 \mu \mathrm{g} / \mathrm{mL})$ was mixed with $1 \mathrm{mM} \mathrm{AgNO}_{3}$ (Aqu) in different ratios (1:5, $1: 10,1: 15,1: 20,1: 25,1: 30$ and $1: 35 \mathrm{v} / \mathrm{v})$ on magnetic stirrer at $35 \pm 3{ }^{\circ} \mathrm{C}$ till the color of solution turned yellow brown. Optimization of AgNPs was brought by measuring UV-Visible spectrum against ethanol in deionized water as a blank with a resolution of $1 \mathrm{~nm}$ between the wavelength ranges of 300 to $800 \mathrm{~nm}$. Dried powder of RE-AgNPs was mixed with $\mathrm{KBr}$, pressed by hydraulic Pellet Press and subjected to FT-IR spectroscopy using "PerkinElmer spectrometer FT-IR Spectrum One”. XRD pattern was analyzed using JEOL JDX 3532 X-ray diffractometer. The dried AgNPs was coated on a carbon tape, subjected to gold coating and analyzed for morphological features through SEM. Size distribution was analyzed through dynamic light scattering (DLS) technique using Malven Zetasizer. For EDX, powdered AgNPs mass was subjected to elemental mapping using the Oxford Inca 200 SEM instrument equipped with a Thermo EDX attachment.

\section{Antileishmanial bioassay}

In vitro anti-leishmanial activity was performed against Leishmania tropica $\left(\mathbf{K W H}_{\mathbf{2}}\right)$ in 96 wells flat bottom plates. From the standardized promastigotes suspension $\left(4 \times 10^{6}\right.$ parasites $\left./ \mathrm{mL}\right)$, $200 \mu \mathrm{L}$ M-199 medium/well with $1 \times 10^{5}$ promastigotes were transferred in 96-well plates, feed with $10 \mu \mathrm{g} / \mathrm{mL}, 50 \mu \mathrm{g} / \mathrm{mL}$ and $100 \mu \mathrm{g} / \mathrm{mL}$ of each of RE and RE-AgNPs, incubated at $26^{\circ} \mathrm{C}$ for 48 hours and the number of promastigotes was counted with the help of Neubauer Hemocytometer in microscope.

\section{Assessment of analgesic activity}

In vivo analgesic potency of RE and RE-AgNPs were determined using Swiss albino mice. The animals were divided into eight groups $(n=6)$, i.e. group I; received saline at $10 \mathrm{ml} / \mathrm{kg}$ bw (i.p); Group II; diclofenac sodium at $10 \mathrm{mg} / \mathrm{kg}$ bw (i.p); groups III, IV \& V; received 50, 100 and 200 $\mathrm{mg} / \mathrm{kg}$ bw of RE, respectively (i.p) and groups $\mathrm{VI}$, VII and VIII received 50, 100 and $200 \mathrm{mg} / \mathrm{kg}$ bw of RE-AgNPs respectively (i.p).

The paw flicking and jumping response of animals at $55 \pm 2{ }^{\circ} \mathrm{C}$ was investigated using 
eddy's analgesiometer, after 30, 60 and $90 \mathrm{~min}$ of drugs administration [9]. The experimental animals were dealt as per protocols of international guidelines for animal studies during the entire period of study [10].

\section{Evaluation of antispasmodic activity}

The overnight fasted mice were divided into eight groups (six mice in each) i.e. group I; received saline at $10 \mathrm{ml} / \mathrm{kg}$ bw, (p.o), group II; received atropine sulphate at $10 \mathrm{mg} / \mathrm{kg} \mathrm{bw}$, (p.o), Group III, IV and V; respectively received doses of 50 , 100 and $200 \mathrm{mg} / \mathrm{kg}$ bw of RE (p.o) and Group VI, VII \& VIII received $50,100 \& 200 \mathrm{mg} / \mathrm{kg}$ bw of RE-AgNPs respectively (p.o). The experimental animals were dealt as per protocols of international guidelines for animal studies during the entire period of study [10]. $0.2 \mathrm{~mL}$ of activated charcoal was given to all animals after $15 \mathrm{~min}$ of doses administration. Animals were sacrificed by cervical dislocation after $30 \mathrm{~min}$ of charcoal treatment, dissected and the intestine was cut down from pyloric to caecum. The distance travelled by the charcoal relative to the total intestinal length was measured as percent propulsion using equation $\mathrm{I}$.

Propulsion $(\%)=\mathrm{CT} / \mathrm{TL} \times 100$

where $\mathrm{CT}=$ charcoal meal traveled in small intestine and $T L=$ Total intestinal (small) length .

\section{Determination of antioxidant potential}

$R E$ and RE-AgNPs were tested for free radical scavenging assay (antioxidant potential) using 2 , 2-diphenyl- 1-picrylhydrazyl (DPPH). Different doses $(10,20,40,60,80$ and $100 \mu \mathrm{g} / \mathrm{mL})$ of RE and RE-AgNPs were mixed with $0.1 \mathrm{mM} \mathrm{DPPH}$. The reaction mixtures were tested for optical density (OD) at $517 \mathrm{~nm}$ after 30,60 and $90 \mathrm{~min}$ of incubation. Untreated DPPH was run as control condition while ascorbic acid treated DPPH was run as a standard antioxidant drug. Antioxidant efficiency (E) was determined as in Eq 2.

$E(\%)=(A b-A t / A b) 100$

where Ab, At are the absorbance of blank and test, respectively samples.

\section{Evaluation of antibacterial activity}

Sterile petri plates filled with Mueller-Hinton agar were autoclaved. Freshly prepared diluted culture of tested bacterial strains was swabbed on Mueller-Hinton agar plates. Wells of $6 \mathrm{~mm}$ diameters were bored, filled with $2 \mathrm{mg} / \mathrm{ml}$ of each streptomycin RE and RE-AgNPs, incubated at 30 ${ }^{\circ} \mathrm{C}$ for $24 \mathrm{~h}$ and evaluated for zone of inhibition (mm).

\section{Statistical analysis}

Data obtained for characterization was plotted using Origin Pro.9.1. The effective concentration for antioxidant potential was determined using Probit analysis in Biostat plus. ANOVA was used for the comparison of mean effect followed by LSD as post-hoc test using SPSS. Antimicrobial, Analgesic and antispasmodic efficacy were expressed as mean \pm SEM using GraphPad Prism 7.

\section{RESULTS}

The phytochemical investigation of RE showed the presence of alkaloids, glycosides, reducing sugars, phenols, proteins, flavonoids, saponins, phytosterols and tannins (Table 1). Biogenic synthesis of RE-AgNPs was confirmed from color of reaction medium which turns from light pale (initial) to characteristic dark brown (final) color. This characteristic color, with a corresponding absorption at around 440 to $460 \mathrm{~nm}$ (Figure 1), arise from the collective oscillation of surface electron (palsmons) of AgNPs in resonance with the light wave. XRD pattern shows diffraction peaks at $2 \theta$ values of $16.92^{\circ}, 38.20^{\circ}, 44.60^{\circ}$ and $64.48^{\circ}$ correspond to Bragg's planes (1 111$),(2$ 0 0), (2 20 ) and (3 $\left.\begin{array}{lll}3 & 1\end{array}\right)$ of silver respectively, confirm crystalline phase of silver with face center cubic (fcc) dimension (Figure 2). The mean crystallite size was calculated using Scherrer's equation based on broadening of the (111) reflection was found to be $14 \mathrm{~nm}$. Size distribution curve (Figure 3 ) shows a bimodal distribution pattern, representing polydispersity of AgNPs with average particle diameter of 30.57 $\mathrm{nm}$. The electron micrograph of AgNPs at various magnification shows spherical to rod shaped morphology with uniform distribution where the average diameter is in the range of 20$58 \mathrm{~nm}$. The larger particulate size is due to the agglomeration of individual particles (Figure 4). EDX spectrum shows the elemental composition of RE-AgNPs. One of the intense peak obtained for $\mathrm{Ag}$ at $3 \mathrm{KeV}$ while other peaks for $\mathrm{Mg}, \mathrm{Al}, \mathrm{K}$, $\mathrm{Ca}, \mathrm{S}, \mathrm{Cl}$ and $\mathrm{Si}$ were also observed (Figure 5). The characteristics X-ray emission peak of $\mathrm{Ag}$ (3 $\mathrm{KeV}$ ) confirms the presence of metallic silver in RE-AgNPs. FT-IR spectrum shows vibration stretches at 1007, 1190, 1596 and $2926 \mathrm{~cm}^{-1}$ (Figure 6). The stretch at $2926 \mathrm{~cm}^{-1}$ assigned to $\mathrm{O}-\mathrm{H}$ of carboxylic acid functional group, while $1007 \mathrm{~cm}^{-1}$ stretch represent $\mathrm{C}-\mathrm{N}$ bond may arise from aliphatic amines. $1190 \mathrm{~cm}^{-1}$ vibrational mode representing $\mathrm{C}-\mathrm{O}$ stretch of alcohols, 
carboxylic acids, esters and ethers. Vibrational stretch of $1596 \mathrm{~cm}^{-1}$ representing $\mathrm{C}-\mathrm{C}$ bond correspond to aromatics and $\mathrm{N}-\mathrm{H}$ bond to amines.

ANOVA results revealed significant $(p<0.05$ ) growth inhibition of all tested bacterial strains. RE-AgNPs was more potent in inhibiting the growth of all tested bacterial strains than RE alone (Figure 7). E. coli was found to be more susceptible to AgNPs than streptomycin, while $P$. aeruginosa was found more resistant to all treatments.

Both RE and RE-AgNPs were tested for their in vitro antileishmanial efficacy against Leishmania tropica. RE exhibited dose dependent mortality of 37,53 and $62 \%$ at 10,50 and $100 \mu \mathrm{g} / \mathrm{mL}$ doses respectively with $L_{50}$ of $34.73 \mu \mathrm{g} / \mathrm{mL}$. REAgNPs revealed pronounced anti-leishmanial property, exhibiting 28, 60 and $82 \%$ lethality at 10,50 and $100 \mu \mathrm{g} / \mathrm{mL}$ respectively with $L_{50}$ of $27.30 \mu \mathrm{g} / \mathrm{mL}$ (Figure 8).

Mice treated with RE at 50, 100 and $200 \mathrm{mg} / \mathrm{kg}$ bw, produced $30.51, \quad 39.71$ and $78.85 \%$ spasmolytic responses compared to atropine sulphate. Experimental animals treated with REAgNPs, revealed dose dependent spasmolytic action, exhibiting 62.29, 77.54 and 83.21\% antispasmodic efficacy at 50, 100 and $200 \mathrm{mg} / \mathrm{kg}$ bw respectively compared to the atropine sulphate (Figure 9). In the paw flick test, pre-oral administration of RE and RE-AgNPs caused significant $(p<0.05)$ dose related analgesia, though less analgesic than standard diclofenac sodium (Figure 10). RE-AgNPs were more potent than RE probably due to their rapid diffusion as they possess considerably small sizes (1 - 100 $\mathrm{nm})$. Antioxidant potential of RE and RE-AgNPs was evaluated using DPPH as a source of free radical. The effective concentrations for $50 \%$ $\mathrm{DPPH}$ inhibition $\left(\mathrm{EC}_{50}\right)$ were 5.84, 5.45 and 3.46 $\mu \mathrm{g} / \mathrm{mL}$ for RE-AgNPs, RE and ascorbate respectively. RE at 30 and 60 min was generally more effective than AgNPs.

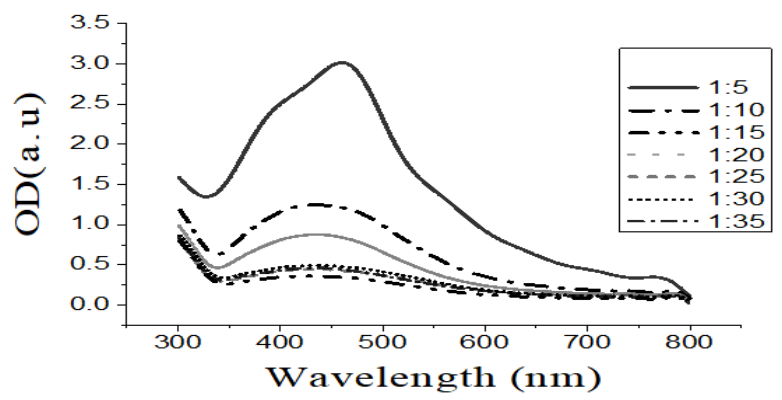

Figure 1: UV-Vis spectra of RE-AgNPs synthesized from different ratios of $\mathrm{RE}$ and $\mathrm{AgNO}_{3}$ showing the absorption spectra in the range of $400-500 \mathrm{~nm}$
Table 1: The qualitative assessment of RE for its phytochemical profile

\begin{tabular}{|c|c|}
\hline Phytometabolites & Result \\
\hline Reducing sugars & ++ \\
\hline Alkaloids & ++ \\
\hline Flavonoids & + \\
\hline Tannins & + \\
\hline $\begin{array}{l}\text { Phytosterols and } \\
\text { triterpenes }\end{array}$ & + \\
\hline Saponin & + \\
\hline Glycosides & + \\
\hline Proteins & + \\
\hline Phenols & ++ \\
\hline
\end{tabular}

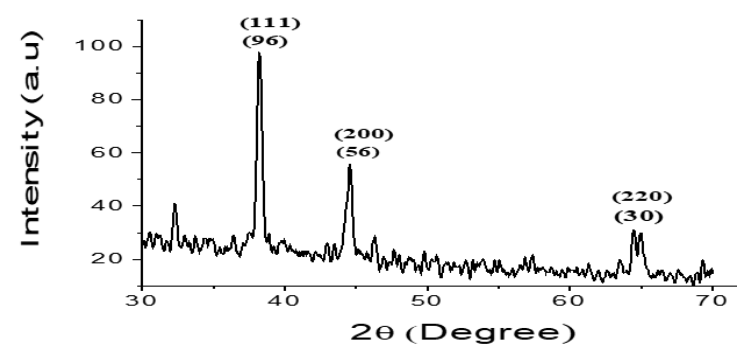

Figure 2: X-ray diffraction pattern of RE-AgNPs showing the crystalline phase

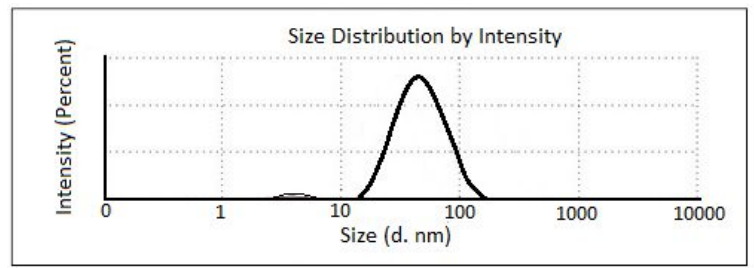

Figure 3: DLS spectrograph of RE-AgNPs showing bimodal size distribution
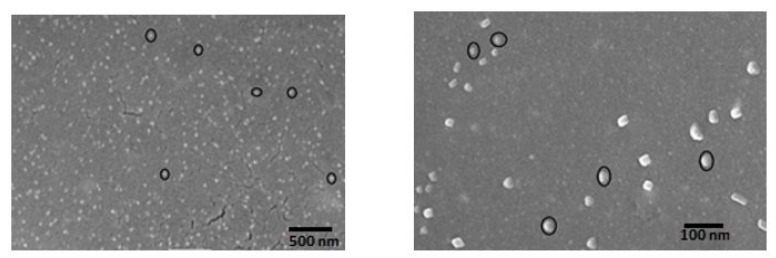

Figure 4: Scanning electron micrographs of REAgNPs showing spherical to rod-shaped morphology with mean diameter ranged between $20-58 \mathrm{~nm}$

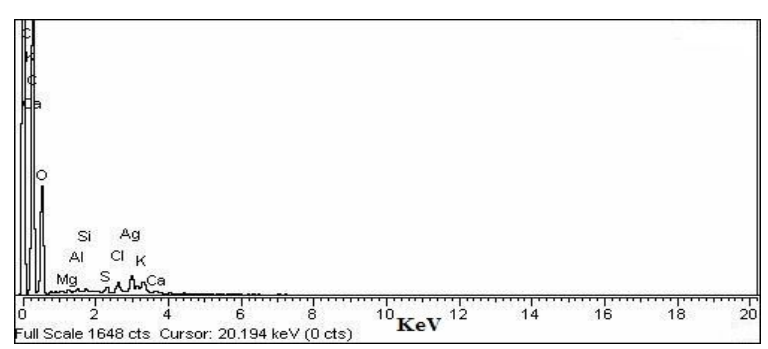

Figure 5: EDS of RE-AgNPs showing Ag signals at $3 \mathrm{KeV}$ representing metallic silver making the core of NPs 


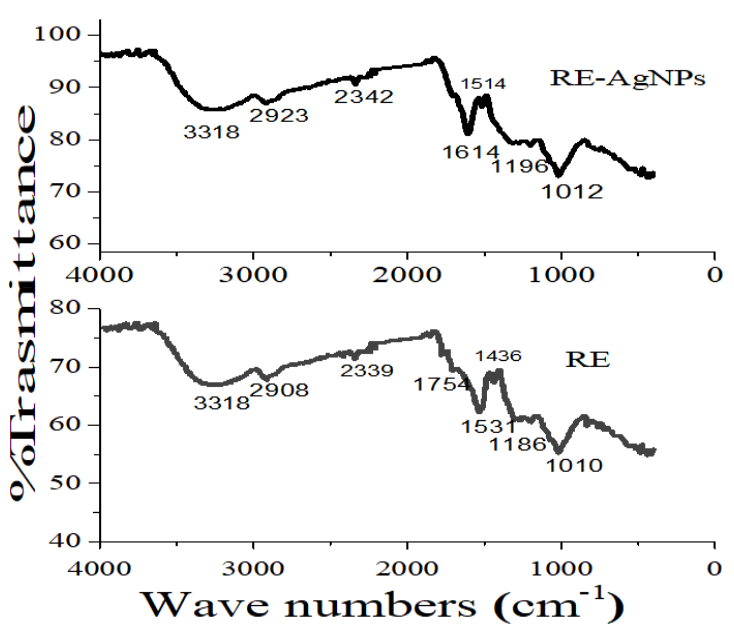

Figure 6: FT-IR spectra of RE and RE-AgNPs representing various stretched for different functional groups

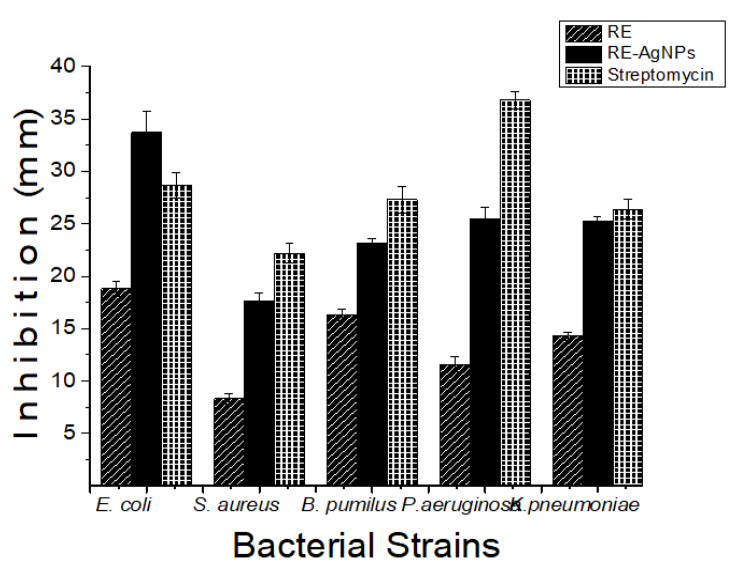

Figure 7: Antibacterial effect of RE and RE-AgNPs against different Gram +ve and Gram -ve bacterial strains in comparison to standard antibacterial agent (streptomycin). OW-ANOAVA reveals statistical significant $(p<0.05)$ inhibition $(\%)$ in linear growth of all tested strains

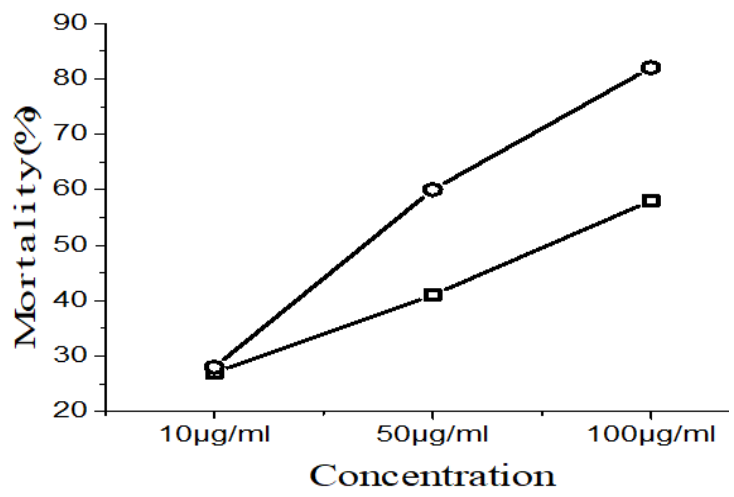

Figure 8: Antileishmanial effect of RE (-口-) and REAgNPs (-०-) against $L$. tropica showing a dose dependent leishmanicidal potency. Student t-Test reflects non-significant $(p>0.05$ ) effect at lower experimental dose but highly significant $(p<0.0 .05)$ effect at higher experimental dose

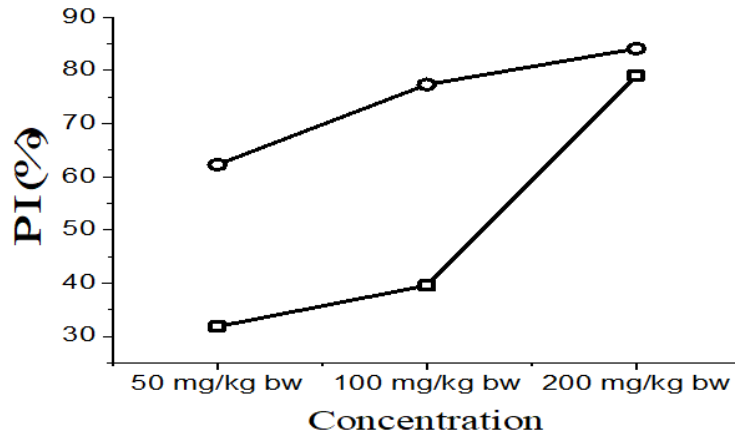

Figure 9: Spasmolytic response (propulsion inhibition "PI") of mice to RE (-口-) and RE-AgNPs (-०-) at various doses. Results revealed highly significant $(p<$ 0.05) differences between RE and AgNPs at 50, 100 and $200 \mathrm{mg} / \mathrm{kg}$ bw

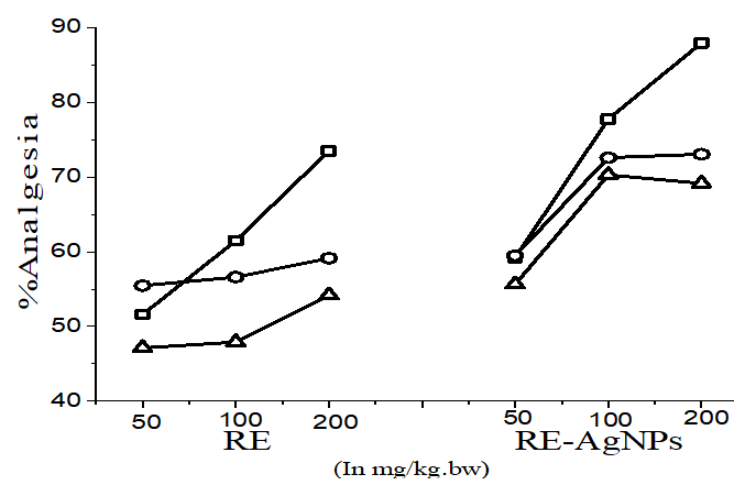

Figure 10: Analgesic response of mice produced after 30 (-口-), 60 (-०-) and 90 minutes (- $\Delta$-) of administration of RE and RE-AgNPs at different time intervals of dose administration.

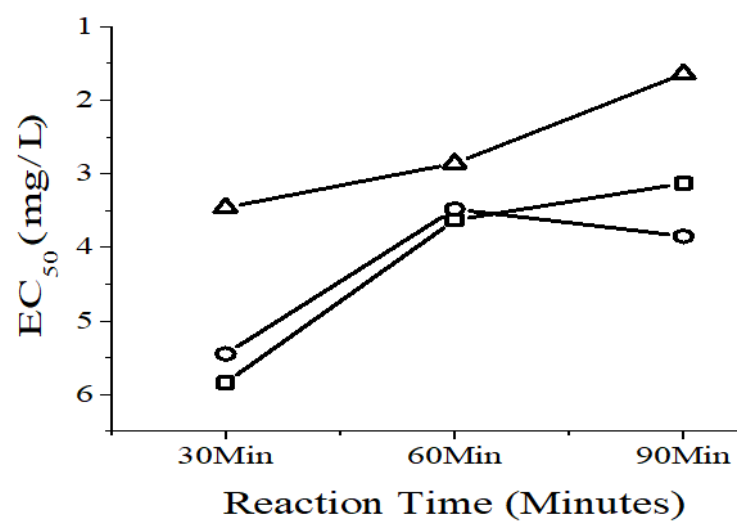

Figure 11: Effective concentration (EC50) for DPPH scavenging by RE (-口-) and RE-AgNPs (-०-) at different interval of reaction mixture. Ascorbic acid $(-\Delta-)$ produced highly significant $(p<0.01)$ scavenging effect against DPPH at all reaction times, RE-AgNPs exhibited significant $(p<0.05)$ antioxidant potential at 90 minutes of reaction time

\section{DISCUSSION}

Phytochemical screening validates the presence of various primary and secondary metabolites. Available literature reveals that aqueous extract 
of E. wallichii rhizome shows the presence of saponins, steroids, and triterpenoids, while alkaloid was absent. Similarly, ethanol extract of E. thymifolia showed the presence of alkaloids, flavonoids, phenols and phytosterols [11]. Synthesis of AgNPs was primaraly confirmed by change in colour of reaction mixture to dark brown which is due to excitation of electron on the surface (SPR) of the newly synthesized nanoparticles [12].

Synthesis of AgNPs accomplished by the reduction of $\mathrm{Ag}^{+}$to $\mathrm{Ag}^{0}$ by phytometabolites, form oligomeric clusters due to agglomeration which lead to the synthesis of colloidal AgNPs. AgNPs shows typical absorption band in visible region due to its characteristic SPR [13]. DLS of REAGNPs showed bimodal size distribution with mean particle size of $30.57 \mathrm{~nm}$ which is different from size distribution revealed by SEM of REAgNPs $(20-58 \mathrm{~nm})$. This difference is due to the fact that electron microscopy considers only the metallic core while DLS includes the ligand shell and determines the hydrodynamic size [14]. EDX spectral analysis of RE-AgNPs shows intense optical absorption approximately at 3 $\mathrm{KeV}$, whereas other less intense peaks for other elements are related to the binding energies of bio-compounds capped the AgNPs [13].

Metallic nanoparticles target multiple cellular components including cell wall, cell membrane, cytoplasmic organelles and DNA, hence there is least chance for microbe to develop resistance [15]. The antibacterial mechanisms of these nanoparticles include binding of positively charged silver to negatively charged DNA and proteins, thus disrupting cellular metabolic pathways $[16,17]$. AgNPs also shown attachments to the bacterial plasma membrane proteins thus disturbing its permeability and respiration, hence making AgNPs, a more potent antimicrobial agents [18].

Accumulation of nanoparticles at targeted site has seems to be in high concentration than normal drugs which often leads to reduced systemic toxicity. AgNPs has the tendency to impair with glycoprotein 63 and lipophosphoglycan found on the leishmanial parasite surface leads to generate oxidative stresses and inhibit the growth of leishmanial parasite [19]. The $\mathrm{Gl}$ tract motility is mainly initiated by the local reflexes and is myogenic. The extrinsic nerves of GI tract have limited role in modulating the peristalsis. Opioid delays gastric emptying through acting on Gl sphincters hence decrease intestinal transit. The smooth muscles showing mark contraction when exposed to neurotransmitter where acetylcholine released from acetylcholine receptors (parasympathetic nerves) [20].

Antispasmodics like atropine and dicyclomine are antagonist of muscarinic acetylcholine receptors and RE-AgNPs exhibited promising antispasmodic effect by antagonizing muscarinic acetylcholine receptors. The spasmolytic effect of REAgNPs was more evident than RE due to the provision of large surface area for antagonism. The current results suggest the involvement of $\mu$ opioid receptors mediated by RE and RE-AgNPs resulting in the generation of analgesic response through central system. Non-thermal nociceptive tests are sensitive to $\mathrm{K}$-agonists opioid while thermal analgesic tests are more sensitive to $\mu$ agonists opioids [21]. The analgesic activity of $E$. wallichii is attributable to the presence of potent secondary metabolites i.e. alkaloids, flavonoids and saponins known for triggering prostaglandins responsible for peripheral nociceptive perception [22]. The ability of phytometabolites to bleaching DPPH purple color indicating their electron donation tendency [23].

Plants with adequate phenolic contents have been observed with potent antioxidant properties. The antioxidant potential is correlated to the phenolic contents of the plants which has the redox potential where they act as proton donor [24]. Other phytometabolites like reducing sugars, tannins and proteins present in plant extracts may also be responsible for antioxidant activity [25]. The promising antioxidant potential of $E$. wallichii is attributed to the presence of reducing biomolecules like phenols, flavonoids, reducing sugars etc. as evident from biochemical tests. RE delivered elevated DPPH scavenging properties than AgNPs, due to the affinity of both $\mathrm{DPPH}$ and $\mathrm{Ag}+$ ions for the reducing agents.

\section{CONCLUSION}

The findings of this study demonstrate that RE has tremendous reducing potential for silver ions and functionalizes the synthesized AgNPs, Biomemic RE-AgNPs significantly inhibits the growth of leishmanial parasite and pathogenic bacterial strains. Although RE produces significant analgesia and spasmolytic effects in mice, RE-AgNPs alleviates antispasmodic and analgesic phenomena and hence has clinical potentials for use in humans as such.

\section{DECLARATIONS}

\section{Conflict of Interest}

No conflict of interest associated with this work. 


\section{Contribution of Authors}

We declare that this work was done by the authors named in this article and all liabilities pertaining to claims relating to the content of this article will be borne by the authors. Rehman Ullah as a principal author designed the study, the synthesized and characterized RE-AgNPs. Sumaira Shah and Saiqa Afriq Jan collectively performed biological screening. Zahir Muhammad statistically analyzed the data and plot the graphs of the manuscript. Siraj ud Din supervised the whole study and wrote the manuscript. We all authors approved the manuscript for publication.

\section{REFERENCES}

1. Kaviya S, Santhanalakshmi J, Viswanathan B. Green Synthesis of Silver Nanoparticles Using Polyalthia longifolia Leaf Extract along with D-Sorbitol: Study of Antibacterial Activity. J Nanotechnol 2011; doi:10.1155/2011/152970.

2. Okafor F, Janen A, Kukhtareva T, Edwards V, Curley M. Green Synthesis of Silver Nanoparticles, Their Characterization, Application and Antibacterial Activity. Int J Environ Res Public Health 2013; 10: 5221-5238.

3. Rai M, Yadav A, Gade A. Silver nanoparticles as a new generation of antimicrobials. Biotechnol Adv 2009; 27: 76-83.

4. Gong $P$, Li H, He X, Wang K, Hu J, Tan W. Preparation and antibacterial activity of $\mathrm{Fe} 3 \mathrm{O} 4$ \&Ag nanoparticles. Nanotechnol 2007; 18: 604-611.

5. Sharma S, Kumar S, Bulchandini BD, Taneja S, Banyal S. Green Synthesis of Silver Nanoparticles and Their Antimicrobial Activity against Gram Positive and GramNegative Bacteria. IJBBR 2013; 4: 341-346.

6. Hazrat A, Nisar M, Shah J, Ahmad S. Ethnobotanical study of some elite plants belonging to Dir, Kohistan valley, Khyber Pukhtunkhwa, Pakistan. Pak J Bot 2011; 43: 787-795.

7. Ahmad E, Arshad M, Ahmad M, Saeed M, Ishaque M. Ethnopharmacological survey of some medicinally important plants of Galliyat areas of NWFP, Pakistan. Asian J Plant Sci 2004; 3: 410-415

8. Khandelwal KR. Practical Pharmacognosy, Techniques and experiments 12th Edition. Nirali Prakashan, Punne India; 2004. 155-160.

9. Toma W, Graciosa JS, Hiruma-Lima CA, Andrade FDP, Vilegas $W$, Souza-Brita ARM. Evaluation of the analgesic and antiedematogenic activities of Quassia amara bark extract. J. Ethnopharmacol 2003; 85: 19-23.

10. National Research Council. Guide for the care and use of laboratory animals. 8th ed. Washington DC. The National Academies Press, 2011; pp 1-246.

11. Garipelli N, Runja C, Potnuri N, Pigili R. Antiinflammatory and anti-oxidant activities of ethanolic extract of Euphorbia thymifolia Linn. Whole plant. Int J Pharm Pharm Sci 2013; 4: 516-519.

12. Leela A, Vivekanandan M. Tapping the unexploited plant resources for the synthesis of silver nanoparticles. Afr $J$ Biotechnol 2008; 3: 3162-3165.

13. Baharara J, Namvar F, Ramezani T, Hosseini N, Mohammad R. Green Synthesis of Silver Nanoparticles using Achillea biebersteinii Flower Extract and Its AntiAngiogenic Properties in the Rat Aortic Ring Model. Molecules 2014; 19: 4624-4634

14. Azizinezhad F, Nasrollahi Z, Sadrnezhaad K. Synthesis of the silver nanoparticles with the using of camomile plant. Eur J Exptal Biol 2014; 4: 124-127.

15. Zhou $Y$, Kong $Y$, Kundu S, Cirillo JD, Liang $H$. Antibacterial activities of gold and silver nanoparticles against Escherichia coli and bacillus Calmette-Guérin. $J$ Nanobiotechnol 2012; 10: 9

16. Feng QL, Wu J, Chen GQ, Cui FZ, Kim TN, Kim JO. A mechanistic study of the antibacterial effect of silver ions on Escherichia coli and Staphylococcus aureus. J Biomed Mater 2000; 52: 662-668.

17. Fazal-Mohamed MI, Arunadevi S, Koperuncholan M, Mubarak MS. Synthesis and antimicrobial activity of some naphthyl ether derivatives. Der Chemica Sinica 2011; 2: 52-57.

18. Panacek A, Kvitek L, Prucek R, Kolar K, Vecerova $R$, Pizurova N, Sharma VK, Nevecna T, Zbori R. Silver Colloid Nanoparticles: Synthesis, Characterization, and Their Antibacterial Activity. J Phy Chem 2006; 110: 16248-16253.

19. Mayelifar K, Taheri AR, Rajabi O, Sazgarnia A. Ultraviolet $B$ efficacy in improving antileishmanial effects of silver nanoparticles. Iran J Basic Med Sci 2015; 18: 677-683.

20. Pasricha PJ. Treatment of disorders of bowel motility and water flux; antiemtics; agents used for billary and pancreatic disease. In: Brunton LL, Lazo JS and Parker KL. (eds.) Goodman \& Gilman's The Pharmacological Basis of Therapeutics; 11th edn. McGraw Hill, New York. 2006; pp 983-1008.

21. Furst SK. Gyires, Knoll J. Analgesic profile of rimazolium as compared to different classes of painkillers. Drug Res 1988; 4: 552-557.

22. Santa-Cecilia FV, Vilela FC, da Rocha CQ, Dias DF, Cavalcante GP, Freitas LAS, Giusti-Paiva A. Antiinflammatory and antinociceptive effects of Garcinia brasiliensis. J Ethnopharmacol 2011; 133: 467.

23. Krishnaiah $D$, Sarbatly $R$, Nithyanandam $R R$. A review of the antioxidant potential of medicinal plant species. Food Bioprod Process 2011; 89: 217-233.

24. Awika JM, Rooney LW, Wu X, Prior RL, Zevallo LC. Screening methods to measure antioxidant activity of sorghum (Sorghum bicolor) and sorghum products. J Agric Food Chem 2003; 51: 6657-6662.

25. Khalaf NA, Shakya AK, Al-Othman A, El-Agbar Z, Farah H. Antioxidant Activity of Some Common Plants. Turk J Biol 2008; 32: 51-55. 